\title{
AKTIVITAS ANTIBAKTERI EKSTRAK AIR REBUSAN DAUN MANGROVE SEGAR Sonneratia alba DI DESA WORI KABUPATEN MINAHASA UTARA
}

\author{
(Antibacterial Activity of Water Extract of Fresh Mangrove Sonneratia alba Leaf Decoction In Wori Village, North Minahasa Regency)
}

\author{
Gisella Aisyah Linggama ${ }^{1}$, Lita A.D.Y. Montolalu ${ }^{2}$, Netty Salindeho ${ }^{2}$, \\ Nurmeilita Taher ${ }^{2}$, Silvana D. Harikedua ${ }^{2}$, Daisy M. Makapedua ${ }^{2}$, Lena Damongilala ${ }^{2}$ \\ ${ }^{1}$ Mahasiswa pada Program Studi Teknologi Hasil Perikanan FPIK UNSRAT Manado. \\ ${ }^{2}$ Staf Pengajar pada Program Studi Teknologi Hasil Perikanan FPIK UNSRAT Manado. \\ E-mail: eghylinggama@gmail.com
}

\begin{abstract}
Sonneratia alba is one type of mangrove whose trees are always green, grow scattered, the height is sometimes up to $15 \mathrm{~m}$ and has compounds that are antibacterial. The purpose of this study was to determine the antibacterial activity found in extracts of Sonneratia alba mangrove leaf decoction in inhibiting Staphylococcus aureus and Escherichia coli bacteria. Using the infusion extraction method by boiling it for 40 and 50 minutes after that it is boiled again with small fire water then dried in an oven with a temperature of $75-80^{\circ} \mathrm{C}$ with an extract concentration of $5 \%$ and $10 \%$, positive control (chloramphenicol), and negative control (aquades). The antibacterial activity assay method used was agar diffusion (disc diffusion Kirby and Bauer) which has been modified. The results obtained were obtained antibacterial activity from extracts of fresh mangrove leaf boiled water extract and antibacterial activity was shown against both test bacteria and explained the broad spectrum antibacterial compounds. Keyword: Sonneratia alba, antibacterial, infusion.

Sonneratia alba merupakan salah satu jenis mangrove yang pohon selalu hijau, tumbuh tersebar, ketinggian kadang-kadang hingga $15 \mathrm{~m}$ dan memiliki senyawa yang bersifat antibakteri. Tujuan dari penelitian ini adalah untuk mengetahui aktivitas antibakteri yang terdapat pada ekstrak air rebusan daun mangrove Sonneratia alba dalam menghambat bakteri Staphylococcus aureus dan Escherichia coli. Menggunakan metode ekstraksi infusa dengan cara direbus selama 40 dan 50 menit setelah itu direbus kembali dengan air api kecil kemudian dikeringkan dalam oven dengan suhu $75-80^{\circ} \mathrm{C}$ dengan konsentrasi ekstrak 5\% dan 10\%, kontrol positif (kloramfenikol), dan kontrol negatif (akuades). Pengujian aktivitas antibakteri yang digunakan adalah difusi agar (disc diffusion Kirby and Bauer) yang telah dimodifikasi. Hasil yang diperoleh yaitu didapatkan aktivitas antibakteri dari ekstrak air rebusan daun mangrove segar dan aktivitas antibakterinya ditunjukkan terhadap kedua bakteri uji dan menjelaskan senyawa antibakteri tersebut berspektrum luas.
\end{abstract}

Kata kunci: Sonneratia alba, antibakteri, infusa.

\section{PENDAHULUAN}

Mangrove merupakan potensi sumberdaya alam yang sangat besar. Berbagai produk dari mangrove dapat dihasilkan baik secara langsung maupun tidak langsung, diantaranya adalah kayu bakar, keperluan rumah tangga, sumber bahan obat tradisional dan memiliki peranan penting dalam melindungi pantai dari gelombang, angin dan badai (Noor et.al., 2006). Tumbuhan Sonneratia alba merupakan salah satu jenis tumbuhan mangrove yang banyak terdapat di Kabupaten Tanjung Jabung Timur Provinsi Jambi. Secara tradisional masyarakat sekitar banyak memanfaatkan buahnya sebagai obat mual (Latief et.al., 2015). Menurut Sukardjo (1984), daun muda Sonneratia alba dapat dibuat sayur atau dapat dimakan mentah sebagai lalapan dan seduhan air buahnya dapat digunakan sebagai obat untuk menghaluskan kulit dan menjaga ketahanan kulit terhadap sengatan panas matahari.

Menurut Boynauw et.al., (2017) ekosistem hutan mangrove di Teluk Labuan Uki Desa Sauk Kabupaten Bolaang Mongondow Sulawesi Utara, telah memberikan manfaat yang besar terhadap masyarakat sekitar, seperti pemanfaatan kayu sebagai kayu bakar, kerangka bangunan rumah tiang kapal, alat penangkapan ikan, serta hiasan untuk menunjang kehidupan mereka, dan menurut Putri et.al., (2016) masyarakat di daerah Desa Tanah Kuning 
Kabupaten Bulungan Kalimantan Utara, memanfaatkan daun Sonneratia alba sebagai bahan tambahan untuk bedak dingin maupun sebagai obat cacar.

Selanjutnya menurut Kurniaji (2014), menyatakan bahwa ekstrak daun mangrove Sonneratia alba mampu menghambat pertumbuhan bakteri Vibrio harveyi secara in Vitro. Berdasarkan fakta tersebut, maka diduga Sonneratia alba mengandung senyawa aktif yang dapat dimanfaatkan bagi kebutuhan manusia. Menurut Dotulong et.al., (2018) bahwa pada daun muda mangrove Sonneratia alba yang diekstrak dengan etanol dengan metode soxhlet terdapat komponen bioaktif yaitu fenol, flavonoid, steroid, saponin, triterpenoid, tanin dan alkaloid yang dapat bekerja sebagai antibakteri.

Berdasarkan uraian di atas, peneliti tertarik untuk melakukan penelitian mengenai uji antibakteri yang terdapat pada daun mangrove muda Sonneratia alba.

\section{METODOLOGI PENELITIAN}

\section{Waktu dan Tempat Penelitian}

Penelitian ini dilaksanakan pada waktu Desember 2018-Mei 2019 di Laboratorium Teknologi Penanganan dan Pengolahan Hasil Perikanan dan Laboratorium Biologi Molekuler \& Farmasitika Laut Fakultas Perikanan dan Ilmu Kelautan Univ. Sam Ratulangi Manado.

\section{Bahan dan Alat}

Bahan yang digunakan dalam penelitian adalah daun muda mangrove Sonneratia alba, Staphylococcus aureus DSM 31 $1^{\mathrm{T}}$ (Deutsche Sammlung Von Mikroorganisme und Zell kulturen GMBH), Escherichia coli DSM 498 (Deutsche Sammlung Von Mikroorganisme und Zell kulturen GMBH), akuades, NB (Nutrient Broth), MHA (Mueller Hinton Agar), agar swallow, kloramfenikol $250 \mathrm{mg}$.

Alat yang digunakan dalam penelitian adalah laminar air flow, autoclave, Spektrofotometri T60 UV-Vis 190-1100 nm, magnetic stirrer, vortex, cawan petri, tabung reaksi, erlenmeyer, gelas ukur, spatula, mikropipet dan tip, pinset, jarum ose, lampu bunsen, botol kaca, kompor, oven Yenaco YNC-OV30L, penggaris, panci, wadah, saringan, gunting, timbangan, kertas cakram, alumunium foil, wrapping, kertas label, tissue.

\section{Pengambilan sampel}

Sampel mangrove Sonneratia alba diambil di Desa Wori Kabupaten Minahasa Utara, Sulawesi Utara. Sampel mangrove yang diambil adalah daun mangrove muda (3-4 helai dari pucuk) dan dibawa ke Laboratorium Teknologi Penanganan dan Pengolahan Hasil Perikanan Universitas Sam Ratulangi untuk dilakukan proses ekstraksi.

\section{Ekstraksi}

Daun dicuci bersih dengan air mengalir kemudian digunting kecil-kecil dan ditimbang sebanyak $1 \mathrm{~kg}$ (dalam satu perlakuan). Didihkan air sebanyak 4 liter (dalam satu perlakuan), setelah air mendidih masukkan daun mangrove yang sudah digunting-gunting dan direbus selama 40 dan 50 menit dengan suhu $97^{\circ} \mathrm{C}$. Kemudian disaring dan air rebusannya dimasukkan ke dalam panci untuk direbus kembali dengan menggunakan api kecil selama 2 jam. Setelah itu dikeringkan di dalam oven selama $10-12$ jam dengan suhu $80^{\circ} \mathrm{C}$. Setelah mendapatkan ekstrak kering, dihitung rendemennya dan kemudian dibuat larutan konsentrasi untuk pengujian antibakteri. (Dirjen POM, 2000 yang dimodifikasi).

\section{Sterilisasi Alat dan Bahan}

Alat-alat yang digunakan dalam penelitian ini seperti cawan petri, tabung reaksi, dan pinset dicuci bersih, dikeringkan, dibungkus kemudian disterilkan dalam oven pada suhu $150^{\circ} \mathrm{C}$ selama 2 jam (sterilisasi kering). Media untuk pertumbuhan mikroorganisme disterilisasi dalam autoclave pada suhu $121^{\circ} \mathrm{C}$ selama 15 menit (sterilisasi basah) (Lay, 1994).

\section{Peremajaan Bakteri Uji}

Bakteri Staphylococcus aureus dan Escherichia coli diambil sebanyak 1 ose dari stok bakteri dan dicampurkan ke media cair Nutrient Broth (NB) $5 \mathrm{~mL}$ dalam tabung reaksi, kemudian ditutup dengan kapas dan dibiarkan selama 24 jam (Dwidjoseputro, 1994 yang dimodifikasi).

\section{Penentuan Optical Density (OD)}

Sediakan 3 kuvet, 1 kuvet dibuat blanko dengan cara masukkan $4 \mathrm{~mL}$ Nutrient Broth ke dalam kuvet dan 2 kuvetnya lagi masukkan masing-masing bakteri sebanyak $0,4 \mathrm{~mL}$ dan tambahkan Nutrient Broth sebanyak 3,6 mL (penghitungan dalam 10 kali pengenceran yang 
diperkecil). Setelah itu diukur absorbansinya dengan menggunakan alat Spektrofotometri UV-VIS dengan panjang gelombang $600 \mathrm{~nm}$ (Ramadan, 2017).

\section{Pembuatan Media Padat MHA}

Pembuatan media ini menggunakan metode tuang (pour plate). Ditimbang MHA (Mueller Hinton Agar) sebanyak 4,8 gram dan agar swallow 2 gram kemudian dimasukkan ke dalam masing-masing erlenmeyer dan dilarutkan dalam akuades sebanyak $200 \mathrm{~mL}$ dan diaduk dengan menggunakan magnetic stirrer. Setelah itu disterilisasi pada suhu $121^{\circ} \mathrm{C}$ selama 15 menit kemudian campurkan bakteri Staphylococcus aureus $24 \mu \mathrm{L}$ di satu erlenmeyer dan bakteri Escherichia coli $38 \mu \mathrm{L}$ di erlenmeyer yang satu lagi dan diaduk dengan magnetic stirrer. Setelah itu dituangkan ke dalam cawan yang sudah diberi kode (Sutedjo, 1996 dalam Pratama 2017 yang dimodikasi).

\section{Pembuatan Kontrol Positif dan Negatif}

Sebagai tolak ukur untuk melihat ada atau tidaknya zona hambat atau aktivitas antibakteri dari sampel yaitu dengan menggunakan obat kloramfenikol sebagai kontrol positif dengan melarutkan $250 \mathrm{mg}$ obat kloramfenikol ke dalam $250 \mathrm{~mL}$ akuades dan akuades sebagai kontrol negatif (Yusriana et.al., 2014 yang dimodifikasi).

\section{Uji AKtivitas Antibakteri}

Pengujian antibakteri yang digunakan adalah cara difusi Kirby-Bauer yang telah dimodifikasi pada konsentrasi 5\% dan 10\%.

\section{Pengujian Aktivitas Antibakteri}

Teteskan ekstrak uji 40 dan 50 menit, kontrol positif dan negatif sebanyak $50 \mu \mathrm{L}$ di kertas cakram dan dibiarkan sampai meresap. Setelah meresap letakkan kertas cakram di atas permukaan media yang sudah dipadatkan dalam cawan. Kemudian dibungkus dengan wrapping lalu diinkubasi selama 24 jam pada suhu ruangan. Setelah itu dilakukan pengamatan dan diukur zona beningnya dengan menggunakan penggaris.

\section{HASIL DAN PEMBAHASAN}

\section{Rendemen}

Hasil rendemen ekstrak air rebusan daun mangrove dengan pelarut air pada perlakuan 40 menit $2,58 \% \pm 0,3$ dan 50 menit $2,66 \% \pm 0,3$. Semakin lama waktu perebusan maka semakin besar rendemen yang dihasilkan.

Tabel 1. Hasil Ekstraksi Air Rebusan Daun Mangrove Sonneratia alba.

\begin{tabular}{|c|c|c|c|c|c|}
\hline \multirow{2}{*}{$\begin{array}{c}\text { Perlakuan } \\
\text { (menit) }\end{array}$} & \multicolumn{3}{|c|}{$\begin{array}{l}\text { Berat Ekstrak } \\
\text { Kering (gram) }\end{array}$} & \multirow{2}{*}{$\begin{array}{l}\text { Rata- } \\
\text { rata } \\
\text { (gram) }\end{array}$} & \multirow{2}{*}{$\begin{array}{l}\text { Rendemen } \\
(\%)\end{array}$} \\
\hline & 1 & 2 & 3 & & \\
\hline 40 & 25,55 & 26,16 & 25,82 & 25,84 & \\
\hline 50 & 26,35 & 26,86 & 26,52 & 26,67 & 2,66 \\
\hline
\end{tabular}

Menurut Wijaya et.al., (2018), hasil rendemen dari ekstrak daun rambai laut (Sonneratia caseolaris L. Engl) dengan metode soxhletasi menghasilkan rata-rata rendemen tertinggi yaitu $28,38 \%$, dengan metode refluks $25,57 \%$, metode maserasi $21,28 \%$, dan dengan metode infundasi menghasilkan rata-rata rendemen terendah yaitu $17,20 \%$. Perbandingan metode ekstraksi juga dapat memberikan hasil yang berbeda-beda.

Tabel 2. Hasil Diameter Zona Hambat Pada Bakteri Escherichia coli

\begin{tabular}{lrrrrrrrr}
\hline \multicolumn{1}{c}{ Perlakuan } & \multicolumn{4}{c}{ Konsentrasi 10\% } & \multicolumn{4}{c}{ Konsentrasi 5\% } \\
& $\mathbf{1}$ & $\mathbf{2}$ & $\mathbf{3}$ & Rata-rata & $\mathbf{1}$ & $\mathbf{2}$ & $\mathbf{3}$ & Rata-rata \\
\hline 40 min & 11,5 & 10,0 & 11,0 & $10,8 \pm 0,8$ & 8,5 & 8,5 & 8,0 & $8,3 \pm 0,3$ \\
50 min & 9,0 & 8,5 & 8,5 & $8,7 \pm 0,3$ & 9,0 & 8,0 & 8,5 & $8,5 \pm 0,5$ \\
Kontrol (+) & 27,0 & 28,5 & 27,5 & $27,7 \pm 0,8$ & 29,0 & 27,5 & 28,0 & $28,2 \pm 0,8$ \\
Kontrol (-) & 0,0 & 0,0 & 0,0 & 0,0 & 0,0 & 0,0 & 0,0 & 0,0 \\
\hline
\end{tabular}

Tabel 3. Hasil Diameter Zona Hambat Pada Bakteri Staphylococcus aureus

\begin{tabular}{lrrrrrrrr}
\hline \multicolumn{1}{c}{ Perlakuan } & \multicolumn{4}{c}{ Konsentrasi 10\% } & \multicolumn{4}{c}{ Konsentrasi 5\% } \\
& $\mathbf{1}$ & $\mathbf{2}$ & $\mathbf{3}$ & Rata-rata & $\mathbf{1}$ & $\mathbf{2}$ & $\mathbf{3}$ & Rata-rata \\
\hline 40min & 8,0 & 8,5 & 8,5 & $8,3 \pm 0,3$ & 8,0 & 7,0 & 8,0 & $7,8 \pm 0,6$ \\
50min & 8,5 & 8,0 & 8,0 & $8,2 \pm 0,3$ & 8,0 & 7,0 & 8,5 & $8,0 \pm 0,9$ \\
Kontrol (+) & 28,5 & 29,5 & 28,5 & $28,8 \pm 0,6$ & 28,0 & 28,0 & 30,0 & $28,7 \pm 1,2$ \\
Kontrol (-) & 0,0 & 0,0 & 0,0 & 0,0 & 0,0 & 0,0 & 0,0 & 0,0 \\
\hline
\end{tabular}

Menurut Davis dan Stout, (1971) dalam Mahmudah dan Atun, (2017) menjelaskan bahwa klasifikasi respon hambatan pertumbuhan bakteri yang dilihat berdasarkan diameter zona bening terdiri atas 4 kelompok yaitu respon lemah (diameter $\leq 5 \mathrm{~mm}$ ), sedang (diameter 5-10 mm), kuat (diameter 10-20 mm), dan sangat kuat (diameter $\geq 20 \mathrm{~mm}$ ). Ekstrak air 
rebusan ini mampu menghambat bakteri Staphylococcus aureus dan Escherichia coli (Tabel 2 dan 3). Hal ini ditunjukkan dengan adanya zona hambat yang terbesar ada pada bakteri Escherichia coli dengan konsentrasi 10\%. Pada perlakuan 40 menit 10,8 $\pm 0,8$ (tergolong kuat) dan zona hambat yang terkecil ada pada bakteri Staphylococcus aureus dengan konsentrasi $5 \%$ pada perlakuan 40 menit 7,8 $\pm 0,6$ (tergolong sedang).

Semakin besar diameter zona hambat yang terbentuk maka semakin sedikit bakteri yang tumbuh. Hal ini, menunjukkan bahwa ekstrak air rebusan mangrove dengan diameter zona hambat yang besar mempunyai aktivitas hambatan dengan merusak membran dan dinding sel bakteri, denaturasi atau menghambat sintesis protein dan sintesa asam nukleat serta mengubah permeabilitas membran (Jawetz et.al., 2007 dalam Widyasanti et.al., 2015).

Dari hasil yang ditujukkan di atas, daya hambat bakteri gram negatif lebih besar zona hambatnya daripada bakteri gram positif. Lebih besar zona hambat pada bakteri Escherichia coli dibandingkan dengan Staphylococcus aureus menunjukkan bahwa untuk menembus membran suatu bakteri gram negatif yang mengandung lebih kuat fosfatidiletanolamin (komponen fosfolipid pada membran), diperlukan komposisi senyawa antibakteri yang lebih kuat lagi. Komposisi fosfatidiletanolamin dalam jumlah banyak akan menyebabkan kurang sensitifnya bakteri terhadap suatu senyawa antibakteri (Widyasanti, et.al., 2015).

Pada penelitian yang telah dilakukan, bahwa kontrol positif (kloramfenikol) jauh lebih efisien untuk menghambat pertumbuhan kedua bakteri uji yaitu zona hambatnya $27,7-$ $28,8 \mathrm{~mm}$. Faktor yang mempengaruhi hal ini karena kloramfenikol memiliki mekanisme aksi menghambat pertumbuhan bakteri dengan mekanisme menghambat sintesis protein dengan jalan mencegah pemanjangan rantai protein dengan menghambat aktivitas enzim peptidil transferase pada ribosom bakteri (Bara, et.al., 2013 dalam Bara, et.al., 2015).

Kontrol negatif yang dalam penelitian ini akuades menunjukkan perbedaan terhadap kontrol positif maupun sampel ekstrak uji lainnya. Pada penelitian ini kontrol negatif berfungsi untuk melihat media yang digunakan tercemar atau tidak. Kontrol tersebut menunjukkan tidak adanya zona hambat pada pengujian antibakteri terhadap bakteri Staphylococcus aureus dan Escherichia coli, sehingga daya hambat yang terbentuk tidak dipengaruhi oleh pelarut melainkan karena aktivitas senyawa aktif yang terdapat pada air rebusan daun mangrove Sonneratia alba (Opa, et.al., 2018).

Senyawa antibakteri dapat digolongkan juga sebagai spektrum luas dan spektrum sempit. Spektrum luas artinya senyawa tersebut bekerja aktif terhadap banyak jenis bakteri baik bakteri Gram positif dan bakteri Gram negatif. Sedangkan spektrum sempit artinya suatu senyawa bekerja aktif hanya terhadap satu golongan bakteri saja baik hanya pada bakteri Gram positif ataupun hanya pada bakteri Gram negatif (WHO, 2014 dalam Opa, et.al., 2018). Hasil penelitian ini menunjukkan bahwa senyawa antibakteri dari ekstrak air rebusan mangrove Sonneratia alba tergolong berspektrum luas dikarenakan kemampuannya menghambat bakteri Gram positif dan Gram negatif.

Berdasarkan penelitian yang dilakukan, senyawa uji ekstrak air rebusan daun mangrove muda Sonneratia alba hanya mampu menghambat pertumbuhan bakteri (bakteriostatik) dan bukan merupakan antibakteri yang dapat membunuh bakteri (bakteriosida).

\section{KESIMPULAN DAN SARAN}

\section{Kesimpulan}

Berdasarkan hasil penelitian, maka disimpulkan bahwa Pertama, ekstrak air rebusan daun mangrove segar Sonneratia alba berhasil memperoleh rendemen sebanyak 40 menit $(2,58 \%)$ dan 50 menit $(2,66 \%)$ dengan melalui proses infusa. Kedua, ekstrak air rebusan daun mangrove segar Sonneratia alba mempunyai aktivitas terbesar pada bakteri Escherichia coli dengan konsentrasi $10 \%$ pada perlakuan 40 menit $10,8 \pm 0,8$ (tergolong kuat) dan aktivitas terkecil ada pada bakteri Staphylococcus aureus dengan konsentrasi 5\% pada perlakuan 40 menit 7,8 $\pm 0,6$ (tergolong sedang). Ketiga, ekstrak ini hanya mampu menghambat pertumbuhan bakteri (bakteriostatik) dan senyawa tersebut berspektrum luas.

\section{Saran}

Perlu dilakukan penelitian yang lebih lanjut untuk menguji ekstrak air rebusan daun mangrove dengan konsentrasi yang berbeda. Disamping itu perlu juga menguji antibakteri ekstrak daun mangrove dengan menggunakan pelarut lain dan bisa dijadikan obat minuman tradisional. 


\section{DAFTAR PUSTAKA}

Bara, R. A., Kandou, G. D., Ola, A.R. B., Posangi, J. 2015. Analisis Senyawa Amtibiotik dari Jamur Simbion yang Terdapat dalam Ascidians Didemnum molle di Sekitar Perairan Bunaken Sulawesi Utara. Jurnal LPPM Bidang Sains dan Teknologi. Volume 2 Nomor 2.

Boynauw, M. Y., Lasabuda, R., Rembet, U. N. W. J. 2017. Studi Manfaat Ekonomi Ekologi Ekosistem Mangrove Di Desa Sauk Kecamatan Lolak Kabupaten Bolaang Mongondow. Jurnal Ilmiah Platax. Volume 5 no 2 .

Dirjen POM. 2000. Parameter Standar Umum Ekstrak Tumbuhan Obat. Jakarta: Departemen Kesehatan RI

Dotulong, V., Wonggo, D., Montolalu, L. A. D. Y. 2018. Phytochemical Content, Total Phenols, and Antioxidant Activity of Mangrove Sonneratia alba Young Leaf Through Different Extraction Methods and Solvents. International Journal of ChemTech Research. Vol. 11 No. 11, pp 356-363.

Dwidjoseputro, D. 1994. Dasar-dasar Mikrobiologi. Djambatan, Jakarta.

Kurniaji, A. 2014. Uji Daya Hambat Ekstrak Daun Mangrove Sonneratia alba pada Bakteri Vibrio harveyi secara In vitro. Skripsi. Fakultas Perikanan dan Ilmu Kelautam. Universitas Halu Oleo, Kendari.

Latief, M., Nazarudin, dan Nelson. 2015. Aktivitas Antioksidan Ekstrak Daun dan Buah Prepat (Sonneratia alba) Asal Tanjung Jabung Timur Provinsi Jambi. Prosiding SEMIRATA bidang MIPA BKS-PTN Barat.

Lay, W. B. 1994. Analisis Mikroba di Laboratorium. Raja Grafindo Persada, Jakarta.

Mahmudah, F. L dan Atun, S. 2017. Uji Aktivitas Antibakteri Dari Ekstrak Etanol Temukunci (Boesenbergia Pandurata) Terhadap Bakteri Streptococcus Mutans. Jurnal Penelitian Saintek, Vol. 22, Nomor 1.

Noor, Y. R., Khazali, M., dan Suryadiputra, I.N.N. 2006. Panduan Pengenalan Mangrove di Indonesia. Cetakan
Kedua. Ditjen PHKA \& Wetlands InternationalIndonesia Programme, Bogor.

Opa, S. L., Bara, R. A., Gerung, G. S., Rompas, R. M., Lintang, R. S. J., Sumilat, D. A. 2018. Uji Aktivitas Antibakteri Fraksi N-Heksana, Metanol dan Air Dari Ascidan Lissoclinum sp. Jurnal Pesisir dan Laut Tropis. Volume 1 Nomor 1.

Pelczar, M.J, Chan, E.C.S. 2008. Dasar-dasar Mikrobiologi. Jakarta: UI-Press. Terjemahan dari: Elements of Micribiology.Lee. J., and Park. J. W. 2017. Roles Of TMAOase In Muscle And Drips Of Alaska Pollock Fillets At Various Freeze/Thaw Cycle. Journal Of Food Processing And Preservation. Hal 1

Pratama, D. 2017. Pembuatan Media Pertumbuhan Mikroba dan Pemindahan Secara Aseptik. Laporan Akhir Praktikum Biokimia. Fakultas Matematika dan Ilmu Pengetahuan Alam. Universitas Andalas Padang.

Putri, R, R., Hasanah, R., dan Kusimaningrum, I. 2016. Uji Aktivitas Antibakteri dan Uji Fitokimia Ekstrak Daun Mangrove Sonneratia alba. Jurnal Sains dan Teknologi Akuakultur. Vol. 2 (1): 43-50. ISSN: 24609226.

Ramadan, F. A. 2017. Substansi Anti Bakteri dari Jamur Endofit Pada Mangrove Avicennia marina. Skripsi. Fakultas Perikanan dan Ilmu Kelautan. Universitas Sam Ratulangi Manado.

Yusriana, C. S., Budi, C. S., Dewi, T. 2014. Uji Daya Hambat Infusa Daun Nangka (Artocarpus heterophyllus) Terhadap Pertumbuhan Bakteri Staphylococcus aureus. Jurnal Permata Indonesia. Volume 5 no 2.

Widyasanti, A. Hajar, S dan Rohdiana, D. 2015. Aktivitas antibakteri ekstrak teh putih terhadap bakteri gram positif dan negatif. Jurnal Penelitian Teh dan Kina, 18(1), 2015: 55-60.

Wijaya, H., Novitasari., Jubaidah, S. 2018. Perbandingan Metode Ekstraksi Terhadap Rendemen Ekstrak Daun Rambai Laut (Sonneratia caseolaris L. Engl). Jurnal Ilmiah Manuntung, 4(1), 79-83. 